412392, Саратовская обл., Самойловский р-н, пос. Краснознаменский.

Тел.: (84548) 2-00-20.
Ключевые слова: эксперимент; элементы структуры; полевая всхожесть; продуктивная кустистость; гидротермический коэффиииент.

\title{
BIOLOGICAL POTENTIAL AND YIELD OF MILLET VARIETIES ON CHERNOZEM OF THE STEPPE ZONE OF THE SARATOV RIGHT BANK
}

Shevtsova Larisa Pavlovna, Doctor of Agricultural Sciences, Professor of the chair "Crop Production, Selection and Genetics", Saratov State Agrarian University named after N.I. Vavilov. Russia.

Druzhkin Anatoliy Phedorovich, Doctor of Agricultural Sciences, Professor of the chair "Crop Production, Selection and Genetics", Saratov State Agrarian University named after N.I. Vavilov. Russia.

Shyurova Natalya Aleksansrovna, Candidate of Agricultural Sciences, Associate Professor of the chair "Crop Production, Selection and Genetics”, Saratov State Agrarian University named after N.I. Vavilov. Russia.

Bashinskaya Oksana Sergeevna, Candidate of Agricultural Sciences, Associate Professor of the chair "Crop Production, Selection and Genetics”, Saratov State Agrarian University named after N.I. Vavilov. Russia.

Schukin Sergey Anatolyevich, Economic Executive, Federal State Unitary Enterprise "Krasavskoe". Russia.
Keywords: experiment; structure elements; field germination; productive bushiness; hydrothermal coefficient.

Experimental material on the development of resource-saving technology millet of growing on the chernozem of the Samoilovka district of the Saratov Right Bank is presented. It has been established that the studied varieties of millet, depending on the prevailing conditions (temperature and humidity), differ markedly in terms of germination and their fullness. The most fullness of seeds has millet Zolotistoe, exceeding the performance of varieties Saratovskoe 12 and Saratovskoe zheltoe by 5-6\%. The greatest safety of the productive plant stand has millet Zolotistoe. Varieties Saratovskoe Zolotistoe and Zolotistoe have the highest grain yield. Each of the studied varieties is characterized by special biological properties and valuable economic characteristics, allowing to combine them in crops with different terms and seeding rates in the conditions of the arid chernozem steppe zone of the Saratov Right Bank.

DOI

\section{КАЧЕСТВО ЗЕРНА ЯРОВОЙ ПШЕНИЦЫ ПРИ СОВРЕМЕННЫХ ТЕХНОЛОГИЯХ ВОЗДЕЛЫВАНИЯ}

\author{
ЩЕРБИНИНА Елена Владимировна, Самарский научно-исследовательский институт сельского \\ хозяйства им. Н.М. Тулайкова
}

ГОРЯнИН Олег Иванович, Самарский научно-исследовательский институт сельского хозяйства им. Н.М. Тулайкова

ДЖАНГАБАЕВ Бауржан Жунусович, Самарский научно-исследовательский институт сельского хозяйства им. Н.М. Тулайкова

ПРОНОВИч Лилия Владимировна, Самарский научно-исследовательский институт сельского хозяйства им. Н.М. Тулайкова

МЕДВЕДЕВ Иван Филиппович, ФГБНУ «НИИСХ Юго-Востока»

Изучено влияние технологий прямого посева на качество зерна и эффективность возделывания яровой твердой пшенищы на черноземе обыкновенном Среднего Поволжъя. Комплексное применение удобрений и средств защиты растений, обеспечивая одинаковую продуктивность и качество зерна, по сравнению с интенсивным фоном традиционной технологии способствовало увеличению условного чистого дохода и уровня рентабельности на 1534,3-1902,7 руб./га и 34,3-34,4 \% соответственно. На показатели качества зерна существенное влияние оказывал ГТк вегетационного периода культуры. Улучшение влагообеспеченности посевов способствовало возрастанию массы 1000 семян с 36,336,9 до 42,8-44,9 г и снижению натуры зерна с 782,0-791,8 до 750,9-767,9 г/л (1,8-5,4 \%). Наибольшее содержание белка установлено в засушливые годы - 15,4-16,3 \%, что на 1,1-3,5 \% больше показателей, полученных во влажные годы. Для повышения эффективности возделывания культуры и улучшения качества зерна предлагается технология прямого посева с комплексным применением защиты растений от болезней, вредителей и сорняков, предпосевным внесением азотных удобрений $N_{30}$

Введение. В настоящее время главным направлением производства растениеводческой продукции является ресурсо- и энергоэкономичность. При этом самый перспективный путь решения данного вопроса - внедрение технологий прямого посева и производственных систем No-till $[2,5,7,13]$. Установлено, что на большинстве черноземов Поволжья, Западной Сибири и юга России для освоения таких технологий нет агрофизических и агрохимических ограничений $[1,3,6,7,9,11]$. При этом слабое освоение технологий прямого посева в России связано с недостаточным научным и теоретическим обоснованием и не комплексным подходом.

Полученные результаты по изучению влияния различных способов обработки почвы и технологий на показатели качества зерна не однозначны. В отдельных опытах применение прямого посева и техноло- гий с минимальной обработкой почвы обеспечивало ухудшение качества зерна, в других исследованиях изменений выявлено не было $[4,8,10,12]$. Зерно яровой твердой пшеницы нецелесообразно использовать на кормовые цели, поэтому в Поволжье не изучали влияние прямого посева с различными уровнями интенсивности на качество зерна.

Цель исследований - изучить влияние технологий прямого посева на качество зерна и эффективность возделывания яровой твердой пшеницы.

Методика исследований. Анализ качества зерна яровой твердой пшеницы проводили в шестипольном зернопаропропашном севообороте на черноземе обыкновенном. Предшественник культуры - соя. При возделывании пшеницы (2011-2017 гг.) изучали следующие технологии (варианты опыта): 
1) традиционная: вспашка на 22-24 см + протравливание семян + гербициды по вегетации культуры Секатор турбо (контроль);

2) контроль + внесение аммиачной селитры перед посевом $\left(\mathrm{N}_{30}\right)+$ инсектициды (Децис Профи - двукратно);

3) ресурсосберегающая: прямой посев АУП-18.05 + протравливание семян + гербициды по вегетации зерновых - Секатор турбо (Фон);

4) фон + биопрепараты в кущение яровой пшеницы (Бионекс Кеми, Фитоспорин);

5) фон + внесение аммиачной селитры перед посевом $\left(\mathrm{N}_{30}\right)$;

6) фон + внесение аммиачной селитры перед посевом $\left(\mathrm{N}_{30}\right)+$ инсектициды (Децис Профи - двукратно);

7) фон + внесение аммиачной селитры перед посевом $\left(\mathrm{N}_{45}\right)+$ инсектициды (Децис Профи - двукратно).

Повторность опыта 3-кратная, размер делянок $1100 \mathrm{M}^{2}$.

Благоприятные погодные условия для роста и развития культуры установлены в 2017 г. (ГТК за май август $=0,94)$. В остальные годы ГТК был на уровне $(0,65-0,74)$, а в 2015 и 2016 гг. ниже среднемноголетних значений $(0,45-0,58)$.

Содержание азота и сырого протеина, количество и качество клейковины, натуру, массу 1000 семян определяли следующими методами: ГОСТ 13496.4-93, ГОСТ ПР54478-2011, 10840-64, 10842-59. Экономическую эффективность рассчитывали общепринятыми методами. Данные обрабатывали с использованием программы AGROS ver. 2.09.

Результаты исследований. В ходе исследований установлено, что урожайность яровой твердой пшеницы существенно зависит от ГТК в период вегетации. В годы с показателем более 0,65 выявлено значительное увеличение урожайности по сравнению с засушливыми годами - с 0,89-1,36 до 1,69-2,40 т/га (24,3-269,7 \%). Достоверное увеличение урожайности от применения удобрений на варианте с прямым посевом получено только в годы с ГТК 0,65 и более 0,20 т/га (11,8 \%) при НСР = 0,18 т/га. Наибольшая прибавка урожая от средств интенсификации получена на варианте с прямым посевом от совместного действия удобрений и инсектицидов. В засушливые годы она составила 0,42-0,46 т/га (46,6-51,1 \%), во влажные 0,51-0,61 т/га (30,2-36,1 \%). При традиционной технологии комплексное применение средств интенсификации обеспечило увеличение урожайности в зависимости от увлажнения вегетационного периода 0,16-0,38 т/га (18,0-23,3\%).

Под влиянием условий и технологий возделывания в значительной степени может изменяться не только урожайность культур, но и качество получаемой продукции. В наших опытах натура и масса 1000 зерен пшеницы незначительно изменялись в зависимости от исследуемых технологий и существенно изменялись от ГТК вегетационного периода (табл. 1).

В среднем за 2015 и 2016 гг. (ГТК = 0,58 и менее) при незначительных изменениях по вариантам установлена низкая масса 1000 семян - 36,3-36,9 г. Улучшение влагообеспеченности посевов способствовало возрастанию массы в среднем за пять лет до 42,8-44,9 г. При этом существенное снижение показателя на интенсивном фоне традиционной технологии (вариант 2) на 2,1 г (4,9 \%) по сравнению с вариантом без удобрений и инсектицидов (вариант 1) связано с увеличением урожайности за счет повышения густоты стеблестоя и озерненности колоса.
Показатели качества зерна в зависимости от ГТК (2011-2017 гг.)

\begin{tabular}{|l|c|c|c|c|c|c|c|c|}
\hline \multirow{2}{*}{ Показатель } & \multicolumn{7}{|c|}{ Вариант } & \multirow{2}{*}{ НСР 0,05 } \\
\cline { 2 - 8 } & 1 & 2 & 3 & 4 & 5 & 6 & 7 & \\
\hline \multicolumn{7}{|c|}{ Масса 1000 зерен, г, пр и ГТ К: } \\
\hline 0,58 и менее & 36,7 & 36,6 & 36,7 & 36,5 & 36,3 & 36,9 & 36,8 & 0,8 \\
\hline 0,65 и более & 44,9 & 42,8 & 44,4 & 44,1 & 44,4 & 44,8 & 43,4 & 1,8 \\
\hline Среднее & 42,5 & 41,0 & 42,2 & 41,9 & 42,1 & 42,5 & 41,5 & 1,5 \\
\hline \multicolumn{7}{|c|}{ Нату ра зерн а, г/л, при ГТ К: } \\
\hline 0,58 и менее & 788,3 & 791,8 & 790,3 & 788,8 & 787,8 & 786,3 & 782,0 & 7,3 \\
\hline 0,65 и более & 758,6 & 765,5 & 757,6 & 758,5 & 750,9 & 763,6 & 767,9 & 15,3 \\
\hline Среднее & 767,1 & 773,0 & 767,0 & 767,1 & 761,4 & 770,1 & 771,9 & 13,0 \\
\hline
\end{tabular}

При анализе натуры зерна выявлена обратная тенденция в зависимости от ГТК. При незначительных колебаниях по вариантам наибольшая натура зерна установлена в засушливые годы - 782,0-791,8 г/л. В более влажные годы показатель снижался на 1,85,4 \%, до 750,9-767,9 г/л.

Один из основных показателей качества зерна пшеницы - содержание белка, значения которого находятся в основном в обратной зависимости от урожайности. В наших опытах эта тенденция была подтверждена. Наибольшее содержание белка отмечали в засушливые годы, при незначительных колебаниях по вариантам, - 15,4-16,3 \%, что на 1,1-3,5 \% больше показателей, полученных во влажные годы (табл. 2).

Внесение азотных удобрений при традиционной технологии, увеличивая урожайность, не снижало содержания белка во все годы исследований. При прямом посеве улучшение минерального питания растений, обеспечивая возрастание продуктивности, способствовало увеличению содержания белка во влажные годы на 0,9-1,8 \%, в среднем за годы исследований на 0,5-1,0 \%.

Таблица 2

Содержание белка в зерне пшеницы в зависимости от условий возделывания, \% (2011-2017 гг.)

\begin{tabular}{|l|c|c|c|c|c|c|c|c|}
\hline \multirow{2}{*}{\multicolumn{1}{|c|}{ ГТК }} & \multicolumn{7}{|c|}{ Вариант } & \multirow{2}{*}{ НСР 0,05 } \\
\cline { 2 - 8 } & 1 & 2 & 3 & 4 & 5 & 6 & 7 & \\
\hline 0,58 и менее & 16,1 & 16,3 & 16,3 & 16,0 & 16,0 & 15,9 & 15,4 & 0,9 \\
\hline 0,65 и более & 13,8 & 13,5 & 12,8 & 12,5 & 13,7 & 14,2 & 14,3 & 0,3 \\
\hline Среднее & 14,7 & 14,6 & 14,1 & 13,9 & 14,6 & 14,9 & 14,7 & 0,5 \\
\hline
\end{tabular}

Применение прямого посева, обеспечивая одинаковую урожайность зерна пшеницы по сравнению с традиционной технологией, не снижало количество и не ухудшало качество клейковины (табл. 3).

Таблица 3

Количество и качество клейковины при разных технологиях возделывания пшеницы (2011-2017 гг.)

\begin{tabular}{|l|c|c|c|c|c|c|c|c|}
\hline \multirow{2}{*}{ Показатель } & \multicolumn{7}{|c|}{ Вариант } & \multirow{2}{*}{ НСР 0,05 } \\
\cline { 1 - 8 } & 1 & 2 & 3 & 4 & 5 & 6 & 7 & \\
\hline Клейковина, \% & 32,6 & 33,9 & 32,0 & 30,6 & 31,9 & 33,5 & 32,4 & 2,0 \\
\hline ИДК & 102,4 & 102,5 & 100,9 & 99,8 & 101,1 & 100,8 & 101,4 & 3,5 \\
\hline
\end{tabular}

Количество клейковины при традиционной технологии составило 32,6-33,9 \%, при прямом посеве 30,6-33,5 \%. При прямом посеве отмечали более высокое качество клейковины - 99,8-101,4, что на 1,0-2,7 \% больше традиционной технологии.

При одинаковых показателях продуктивности и качества зерна технологии прямого посева с максимальным уровнем интенсивности (варианты 6, 7) обеспечивали увеличение условного чистого дохода и повышение уровня рентабельности по сравнению с традиционной технологией (интенсивный фон, вари- 
ант 2) на 1534,3-1902,7 руб./га и 34,3-34,4 \% соответственно. Сравнение варианта 1 с вариантами 6 и 7 показало преимущество последних: условный чистый доход и уровень рентабельности возрастали до 3826,4-4184,3 руб./га и 47,0-47,1 \% соответственно.

Заключение. Полученные данные свидетельствуют о том, что технологии прямого посева более отзывчивы на средства интенсификации по сравнению с традиционной технологией. На показатели качества зерна существенное влияние оказывает ГТК вегетационного периода культуры. Улучшение влагообеспеченности посевов способствовало возрастанию массы 1000 семян с 36,3-36,9 до 42,8-44,9 г и снижению натуры зерна с 782,0-791,8 до 750,9-767,9 г/л (1,8-5,4 \%). Наибольшее содержание белка установлено в засушливые годы - 15,4-16,3 \%, во влажные годы - 1,1-3,5 \%.

Для повышения эффективности возделывания культуры и качества зерна предлагается технология прямого посева с комплексным применением защиты растений от болезней, вредителей и сорняков, предпосевным внесением азотных удобрений $\mathrm{N}_{30}$.

\section{СПИСОК ЛИТЕРАТУРЫ}

1. Власенко А.Н., Власенко Н.Г., Коротких Н.А. Проблемы и перспективы разработки и освоения технологии No-till на чернозёмах лесостепи Западной Сибири // Достижения науки и техники АПК. - 2013. - № 9. С. $16-19$.

2. Горянин О.И., Горянина Т.А. Перспективы возделывания полевых культур в Среднем Заволжье // Успехи современного естествознания. - 2018. - № 4. - С. 49-53.

3. Данилов А.Н., Летучий А.В. Сравнительная оценка удобрений и способов основной обработки почвы в полевом севообороте // Аграрный научный журнал. - 2016. - № 6. - С. 3-7.

4. Ерофеев С.E. Технология возделывания яровой пшеницы на чернозёме выщелоченном, адаптированная к условиям Ульяновской области // Пути решения проблем повышения адаптивности, продуктивности и качества зерновых и кормовых культур: материалы Междунар. науч.-практ. конф., посвящ. 100-летию Самарского НИИСХ и 70-летию Поволжского НИИСС. - Самара, 2003. - С. $123-124$.

5. Жученко А.А. Проблемы ресурсосбережения в процессах интенсификации сельскохозяйственного производства // Проблемы адаптивной интенсификации земледелия в Среднем Поволжье: сб. науч. тр., посвящ. 135-летию со дня рождения Н.М. Тулайкова / ГНУ Самарский НИИСХ. Самара, 2012. - С. 8-33.
6. Казаков Г.И., Милюткин В.А. Экологизация и энергосбережение в земледелии Среднего Поволжья. - Самара: РИЦ СГСХА, 2010. - 245 с.

7. Концепция формирования современных ресурсосберегающих комплексов возделывания зерновых культур в Среднем Поволжье / сост. В.А. Корчагин. - 2-е изд., перераб. и доп. - Самара, 2008. - 88 с.

8. Кузина Е.В., Якунин А.И. Изменение урожайности озимой пшеницы и качества зерна в зависимости от способов основной обработки почвы и уровня удобрений // Аграрный научный журнал. - 2016. - № 11. - С. 24-29.

9. Нарушев В.Б., Косолапов Д.С., Одиноков Е.В. Влияние прямого посева на плодородие почвы и продуктивность полевых культур в степном Поволжье // Плодородие. 2013. - № 5 (74). - С. 6-8.

10. Огарёв В.Ф. Поле и урожай. - Саратов: Приволж. кн. изд-во, 1990. - 256 с.

11. Прямой посев полевых культур и его эффективность / Г.Р. Дорожко [и др.] // Земледелие. - 2013. - № 8. - С. 20-23.

12. Способ основной обработки, урожай и качество зерна / Г.Н. Черкасов [и др.] // Земледелие. - 2011. - № 5. - С. 18-19.

13. Чекаев Н.П., Вдасова Т.А., Кочмина Е.О. Изменение агрофизических показателей чернозёма выщелоченного и урожайности яровой пшеницы в условиях внедрения технологий No-till / / Нива Поволжья. - 2015. - № 2 (35). - С. 74-79.

Щербинина Елена Владимировна, младиий научный сотрудник отдела земледелия и новых технологий, Самарский научно-исследовательский институт сельского хозяйства им. Н.М. Тулайкова. Россия.

Горянин Олег Иванович, $\partial-p$ c.- $x$. наук, главный научный сотрудник отдела земледелия и новых технологий, Самарский научно-исследовательский институт сельского хозяйства им. Н.М. Тулайкова. Россия.

Джангабаев Бауржан Жунусович, старший научный сотрудник отдела земледелия и новых технологий, Самарский научно-исследовательский институт сельского хозяйства им. Н.М. Тулайкова. Россия.

Пронович Лилия Владимировна, научный сотрудник лаборатории технолого аналитического сервиса, Самарский научно-исследовательский институт сельского хозяйства им. Н.М. Тулайкова. Россия.

446253, Самарская обл., п.г.т. Безенчук, ул. К. Маркса, 41. Тел.: (84676) 2-11-40.

Медведев Иван Филиппович, $\partial-p$ c.- $x$. наук, проф., главный научный сотрудник отдела экологии агроландшафтов, ФГБНУ «НИИСХ Юго-Востока». Россия.

410010, г. Саратова, ул. Тулайкова, 7.

Тел.: (8452) 64-77-39.

Ключевые слова: прямой посев; яровая твердая пшенииа; качество зерна.

\section{QUALITY OF SPRING WHEAT GRAIN AT CULTIVATING WITH MODERN TECHNOLOGIES}

Shcherbinina Elena Vladimirovna, Junior researcher of the Department of agriculture and new technologies, Samara Agricultural Research Institute named after N.M. Tulaykov. Russia.

Goryanin Oleg Ivanovich, Doctor of Agricultural Sciences, Chief Researcher of the Department of agriculture and new technologies, Samara Agricultural Research Institute named after N.M. Tulaykov. Russia.

Dzhangabaev Baurzhan Zhunusovich, Senior Researcher of the Department of agriculture and new technologies, Samara Agricultural Research Institute named after N.M. Tulaykov. Russia.

Pronovich Lilia Vladimirovna, Researcher of the Department of agriculture and new technologies, Samara Agricultural Research Institute named after N.M. Tulaykov. Russia.

Medvedev Ivan Philippovich, Doctor of Agricultural Sciences, Professor, Chief Researcher of the Department of ecology of agricultural landscapes, Agricultural Research Institute for the South-East Region. Russia.

Keywords: direct sowing; spring durum wheat; grain quality.

The results of studies in the grain-crop rotation (2011-2017 years) to study the impact of direct seeding technologies on the quality of grain and the efficiency of spring durum wheat cultivation on the chernozems of the middle Volga region are presented. Grain of spring durum wheat is impractical to use for feed purposes, while in the Volga region has not been studied the effect of direct sowing with different levels of intensity on the quality of grain. Favorable weather conditions for the growth and development of culture established in 2017 (SCC for may-August=0.94). In other years, the SCC was at and below the average annual values (0.45-0.74). Complex application of fertilizers and plant protection products providing the same productivity and quality of grain, in comparison with the intensive background of traditional technology, contributed to an increase in conditional net income and profitability by 1534.3-1902.7 rubles/ha and 34.3-34.4\%, respectively. Compared with traditional technology without the use of fertilizers and insecticides, the advantage of the best options increased to 3826.4-4184.3 rubles/ha and 47.0-47.1 \%. The indicators of grain quality significantly influenced the SCC vegetation period of culture. Improved water availability of crops contributed to the increase in weight of 1000 seeds from 36.3-36.9 $\mathrm{g}$ to 42.8-44.9 $\mathrm{g}$ and reduce the nature of grain from 782.0-791.8 $\mathrm{g} / \mathrm{t}$ to $750.9-767.9 \mathrm{~g} / \mathrm{l}(1.8-5.4 \%)$. The highest protein content was found in dry years - 15.4-16.3\%, which is 1.1-3.5\% more than in wet years. On the basis of the conducted research to improve the efficiency and quality of grain at the level of the required indicators, the technology of direct sowing with complex application of plant protection against pests and weeds, presowing application of nitrogen fertilizers N30 is proposed. 